$\begin{array}{lllllllll}E & D & I & T & O & R & I & A & L\end{array}$

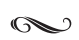

\title{
Sobre o Academia na Serra II
}

Os Anais da Academia Nacional de Medicina (ANM), a primeira revista científicocultural de nosso país, circulam ininterruptamente desde a primeira metade do século XIX. Embora não indexada, retrata a história de nossa Academia nestes últimos 190 anos, e ilustram a produção científica de muitos de nossos acadêmicos.

Neste número, retratamos a participação da ANM na Serra Fluminense, onde o acadêmico e professor Cláudio Tadeu Daniel-Ribeiro organizou um excelente simpósio, em comunhão com a Faculdade de Medicina de Petrópolis e com o apoio da Fiocruz.

Esta atividade da ANM tem por principal objetivo contribuir e estimular aos jovens estudantes de Medicina a tornarem-se amantes e admiradores da arte médica.

Ao ouvir, conhecer e assistir às apresentações de grandes mestres, o sonho é despertado, e o amor aos estudos e a dedicação à ciência crescem.

Ao unir ANM com qualquer escola de Medicina estamos crescendo como célula mater e procriando vontade, imaginação e esperança.

O acadêmico Cláudio Tadeu Daniel-Ribeiro, pesquisador sênior da Fiocruz, é um entusiasta da transmissão do conhecimento e, ao homenageá-lo por mais este evento, o reconheço como um dos grandes idealizadores de nossa geração.

À Faculdade de Medicina de Petrópolis, minha admiração pelos mais de 50 anos dedicados ao ensino médico e à educação de seus alunos. Parabéns!

Acadêmico José Galvão Alves Editor dos Anais da Academia Nacional de Medicina 